\title{
Hubungan Dukungan Sosial dengan Manajemen Diri pada Penderita Diabetes Melitus (DM) Tipe 2
}

\author{
Lenni Sastra $^{1 \text { ** }}$, Afrizal ${ }^{2)}$, Adella Fitri Mulya ${ }^{3)}$ \\ 1),2),3) Prodi S1 Keperawatan STIKes MERCUBAKTIJAYA Padang \\ Jl. Jamal Jamil Pondok Kopi Siteba Padang \\ email : lenni_sastra@yahoo.com
}

\begin{abstract}
ABSTRAK
DM tipe 2 merupakan penyakit kronis yang membutuhkan manajemen diri untuk mencegah komplikasi. Perilaku manajemen diri diabetes mencakup diet, latihan fisik, medikasi, pemantauan glukosa darah dan perawatan kaki. Tujuan penelitian adalah untuk mengetahui hubungan dukungan sosial dengan manajemen diri pada penderita DM tipe 2 di Poli Klinik Khusus Penyakit Dalam RSUP Dr. M. Djamil Padang. Jenis penelitian adalah survei analitik korelasional dengan pendekatan cross sectional study. Populasi pada penelitian ini adalah seluruh pasien yang berkunjung di rawat jalan Poli Klinik Khusus Penyakit Dalam RSUP Dr. M. Djamil Padang dengan jumlah sampel 61 orang yang diambil dengan menggunakan metode accidental sampling. Instrumen penelitian dengan menggunakan kuesioner. Analisa univariat ditampilkan pada tabel distribusi frekuensi dan bivariat dengan uji chi-square dengan kepercayaan 95\%. Hasil penelitian menunjukkan lebih dari separoh pasien DM Tipe $2(55,7 \%)$ memiliki manajemen diri yang kurang baik dan lebih dari separoh $(60,7 \%)$ memiliki dukungan sosial yang kurang baik. Terdapat hubungan antara dukungan sosial dengan manajemen diri di Poli Klinik Khusus Penyakit Dalam RSUP Dr. M. Djamil Padang $(p$ value $=0.002)$. Kesimpulan dari hasil penelitian dukungan sosial mempengaruhi manajemen diri. Disarankan kepada petugas kesehatan agar dapat meningkatkan manajemen diri dengan mengefektifkan dukuangnmelalui pembentukan klub diabetes, perawat sebagai fasilitator untuk menghubungkan pasien DM tipe 2 dengan sumber dukungan sosial baik keluarga, tenaga kesehatan, kelompok pendukung untuk mempertahankan kondisi emosional pasien ke arah yang adaptif.
\end{abstract}

Kata Kunci : Dukungan Sosial, Manajemen Diri, Diabetes Mellitus 


\begin{abstract}
Type 2 diabetes is a chronic disease that requires self-management to prevent complications. Self-management behavior of diabetes includes diet, physical exercise, medication, blood glucose monitoring and foot care. The purpose of this study was to determine the relationship of social support with self-management in patients with type 2 diabetes in the Special Outpatient of Internal Medicine Dr. M. Djamil Padang. The type of research is correlational analytic survey with cross sectional study approach. The population in this study were all patients who visited in Special Outpatient of Internal Medicine Dr. M. Djamil Padang with a sample of 61 people taken by accidental sampling method. The research instrument using questionnaire. Univariate analysis was shown in frequency distribution table and bivariate with chi-square test with $95 \%$ confidence. The results showed that more than half of DM Type 2 patients (55.7\%) had poor selfmanagement and more than half (60.7\%) had poor social support. There is a relationship between social support and self-management in the Special Outpatient of Internal Medicine Dr. M. Djamil Padang ( $p$ value = 0.002). The conclusion of the results of this study is social support affect self-management. It is recommended that health workers be able to improve self-management by streamlining support through the establishment of a diabetes club, nurses as facilitators to connect type 2 DM patients with a source of social support for both families, health workers, support groups to maintain the patient's emotional state in an adaptive direction.
\end{abstract}

Keywords: Social Support, Self Management, Diabetes Mellitus 


\section{PENDAHULUAN}

Diabetes melitus (DM) merupakan salah satu penyakit dengan angka kejadian yang terus meningkat. Jenis DM yang terbanyak adalah DM tipe 2 yaitu sekitar $90 \%$ (WHO, 2013). Berdasarkan laporan Internasional Diabetes Federation (IDF) jumlah penderita DM tipe 2 di dunia pada tahun 2012 lebih kurang 371 juta. World Health Organization (WHO) memperkirakan jumlah ini akan meningkat pada tahun 2030 menjadi 592 juta. Asia Tenggara pada tahun 2013 berada pada peringkat ke dua tertinggi didunia dengan jumlah penderita DM tipe 2 sebanyak 72 juta jiwa. Jumlah ini diperkirakan akan meningkat $70.6 \%$ menjadi 122,8 juta penderita pada tahun 2035 (IDF, 2013).

Di Indonesia jumlah penderita DM terus mengalami peningkatan. Indonesia adalah negara yang menduduki peringkat ke-4 terbanyak jumlah penderita DM tipe 2 berdasarkan survey WHO tahun 2013. Di Sumatera Barat, prevalensi kejadian DM adalah 1,8\% dengan proporsi kematian 6,9\%. Penyakit DM merupakan penyakit yang berada pada peringkat ke 2 dari 10 penyakit terbanyak di Sumatera Barat pada tahun 2014 dengan prevalensi $1.8 \%$ dengan proporsi (RISKESDAS, 2014).

Angka kejadian penderita DM yang besar berpengaruh kepada peningkatan komplikasi. Menurut Soewondo dkk (2010 dalam purwanti , 2013) sebanyak 1785 penderita diabetes melitus di Indonesia yang mengalami komplikasi neuropati $(63,5 \%)$, retinopati $(42 \%)$, nefropati (7,3\%), makrovaskuler (6\%), mikrovaskuler (6\%), dan kaki diabetik (15\%). Komplikasi diabetes dapat terjadi karena beberapa faktor yaitu genetik, lingkungan, gaya hidup, terlambatnya terdiagnosis DM, dan tidak menjalani pengobatan secara teratur.

Pengelolaan atau manajemen diri diabetes merupakan hal yang sangat penting bagi setiap individu dalam pengelolaan penyakit ini serta penting dalam mengendalikan dan mencegah komplikasi diabetes (Xu et al. 2008 dalam Astuti, 2014). Penelitian yang dilakukan oleh Gultom (2012), didapatkan hasil gambaran tentang manajemen DM rendah. Pada penelitian Mahmudin (2012) didapatkan hasil yang menunjukkan 80,3\% mayoritas responden memiliki manajemen diri DM tipe 2 yang baik pada aspek nutrisi dan kepatuhan pada terapi obat $91,8 \%$, sementara tidak baik pada latihan fisik $52,5 \%$ dan monitor gula $50,8 \%$.

Manajemen diri merupakan hal yang lebih menonjol pada DM tipe 2 dibandingkan dengan DM tipe 1. Salah satu pemicu DM tipe 2 ialah gaya hidup, sehingga pasien dengan DM tipe 2 akan mempunyai kondisi yang lebih baik apabila memperbaiki gaya hidupnya dan begitu juga sebaliknya. Faktor gaya hidup dapat diubah yaitu melakukan olahraga, menurunkan berat badan bagi mereka yang mempunyai berat badan berlebih, manajemen stres, dan mengontrol diet atau kebiasaan makan agar kadar glukosa tetap normal, sebelum dibantu oleh obat dan insulin (Taylor, 2006 dalam Hasanat, 2015).

Ada beberapa faktor yang mempengaruhi manajemen diri pada pasien DM diantaranya yaitu usia, lama menderita DM, pengetahuan, spiritual, efikasi diri, dukungan sosial, social environmental support 
dan social problem-solving. Dalam beberapa penelitian dikatakan bahwa orang-orang dengan DM tipe 2 yang memiliki dukungan sosial yang baik, dan kemampuan pemecahan masalah sosial yang efektif akan mampu untuk mengatasi hal yang menyebabkan stress karena penyakit dan dapat meningkatkan prilaku manajemen diri terhadap penyakitnya menurut Nam et al. (2011 dalam Hunt et al., 2012).

Dukungan sosial merupakan bantuan yang diterima dari orang lain yang memiliki potensi untuk meningkatkan kesejahteraan penerima menurut Schaffer (2009 dalam Hunt et al., 2012). Dukungan sosial dapat berupa emosional/informasi, kasih sayang serta interaksi sosial yang posotif yang diberikan kepada individu. Penelitian yang dilakukan oleh Goetz et al, (2012); Schiotz et al, (2012) menunjukkan bahwa dukungan sosial sangat penting dan berpengaruh terhadap kesejahteraan penyandang DM tipe 2. Dukungan sosial sangat membantu penyandang DM tipe 2 untuk meningkatkan kontrol terhadap diabetes. Kurangnya dukungan sosial berdampak pada rendahnya aktifitas penyandang DM, distres emosianal yang lebih besar, ketidakteraturan dalam kebiasaan diet dan menurunnya frekuensi untuk pemeriksaan kaki.

Berdasarkan survei awal didapatkan data bahwa mayoritas kasus diabetes di Poli Klinik Khusus Penyakit Dalam RSUP Dr. M. Djamil Padang ialah Diabetes Melitus tipe 2. Peneliti melakukan wawancara kepada 10 orang dengan pasien DM tipe 2 yang berkunjung, dan didapatkan hasil $70 \%$ memiliki kebiasaan makan yang tidak baik, dimana sering makan-makanan berlemak dan jarang mengkonsumsi sayur dan buah serta jarang melakukan aktifitas fisik. Didapatkan $70 \%$ memiliki kebiasaan latihan yang kurang, 60\% tidak menggunakan obat dan atau insulin sesuai yang disarankan, $80 \%$ tidak memeriksa glukosa darah secara rutin, dan $70 \%$ tidak melakukan perawatan kaki secara rutin. $90 \%$ pasien mengatakan khawatir akan kemungkinan komplikasi yang ditimbulkan oleh penyakitnya, $80 \%$ merasa kurang yakin melakukan perawatan mandiri seperti memeriksa glukosa darah mandiri, diet, olahraga dan perawatan kaki. $80 \%$ mengatakan sangat membutuhkan dukungan sosial dalam memotivasi mereka dalam melakukan pengobatan penyakitnya serta menghindari komplikasi. Berdasarkan latar belakang diatas peneliti tertarik untuk melakukan penelitian mengenai hubungan dukungan sosial dengan manajemen diri pada Penderita Diabetes Melitus tipe 2 di Poli Klinik Khusus Penyakit Dalam RSUP Dr. M. Djamil Padang

\section{METODE PENELITIAN}

Penelitian ini merupakan penelitian analitik korelasional dengan pendekatan cross sectional. Populasi penelitian ini adalah seluruh pasien DM Tipe 2 yang berkunjung di rawat jalan Poli Klinik Khusus Penyakit Dalam RSUP Dr. M. Djamil Padang dengan jumlah sampel sebanyak 61 orang yang diambil dengan teknik accidental sampling. Instrument yang digunakan untuk penelitian ini adalah dengan menggunakan kuesioner manajemen diri dari Summary of Diabetes Self Care Activities Revised (SDSCA) dan kuesioner dukungan sosial dari Medical Outcomes Study 
(MOS). Uji statistik yang digunakan adalah uji Chi-Square.

\section{HASIL DAN PEMBAHASAN}

Tabel 1 Distribusi Frekuensi Manajemen Diri Pasien DM Tipe 2 di Poli Klinik Khusus Penyakit Dalam RSUP Dr. Djamil Padang

\begin{tabular}{lcc}
\hline Manajemen Diri & $\boldsymbol{f}$ & $\boldsymbol{\%}$ \\
\hline Kurang Baik & 34 & 55.7 \\
Baik & 27 & 44.3 \\
\hline Total & $\mathbf{6 1}$ & $\mathbf{1 0 0}$ \\
\hline
\end{tabular}

Tabel 2 Distribusi Dukungan Sosial DM Tipe 2 di Poli Klinik Khusus Penyakit Dalam RSUP Dr. M. Djamil Padang

\begin{tabular}{l|cc}
\hline Dukungan Sosial & $\boldsymbol{f}$ & $\boldsymbol{\%}$ \\
\hline Kurang Baik & 37 & 60.7 \\
Baik & 24 & 39.3 \\
\hline Total & $\mathbf{6 1}$ & $\mathbf{1 0 0}$ \\
\hline
\end{tabular}

Tabel 3 Distribusi tabulasi silang variabel manajemen diri dan dukungan sosial pasien DM Tipe 2 di Poli Klinik Khusus Penyakit Dalam RSUP Dr. M. Djamil Padang

\begin{tabular}{|c|c|c|c|c|c|c|}
\hline \multirow{3}{*}{$\begin{array}{c}\text { Dukun } \\
\text { gan } \\
\text { Sosial }\end{array}$} & & \multicolumn{4}{|c|}{ Manajemen Diri } & \multirow[t]{2}{*}{$\begin{array}{l}p \text { - } \\
\text { value }\end{array}$} \\
\hline & & \multicolumn{2}{|c|}{ Kurang Baik } & \multicolumn{2}{|c|}{ Baik } & \\
\hline & $f$ & $\%$ & $f$ & $\%$ & $f$ & \\
\hline Kurang & 27 & 73 & 10 & 27 & 37 & \\
\hline Baik & & & & & & 0.002 \\
\hline Baik & 7 & 29.2 & 17 & 70.8 & 24 & \\
\hline Total & 34 & 55.7 & 27 & 44.3 & 61 & \\
\hline
\end{tabular}

Berdasarkan tabel 1 dan 2 dapat dilihat bahwa lebih dari separoh $(55.7 \%)$ pasien DM tipe 2 memiliki manajemen diri yang kurang baik dan lebih dari separoh (60.7\%) pasien DM tipe 2 memiliki dukungan sosial yang kurang baik. Berdasarkan tabel 3 dapat dilihat bahwa proporsi penderita DM tipe 2 yang memiliki manajemen diri kurang baik lebih banyak ditemukan pada pasien dengan dukungan sosial kurang baik $(73 \%)$ dibandingkan dengan dukungan sosial baik (29.2\%). Hasil uji statistic chi square diperoleh nilai $\mathrm{p}=0.002$ ( $p$ value $<0.05)$, maka dapat disimpulkan bahwa terdapat hubungan yang antara dukungan sosial dengan manajemen diri pasien DM Tipe 2.

Penelitian ini memperlihatkan bahwa lebih dari separoh (55.7\%) pasien DM Tipe 2 memiliki manajemen diri yang kurang baik. Hal ini dibuktikan dari hasil pengumpulan data yang menunjukkan dalam satu minggu terakhir sebanyak $63,9 \%$ pasien DM Tipe 2 hanya satu hari memeriksa gula darah sesuai dengan yang disarankan oleh petugas kesehatan, sebanyak $41 \%$ pasien tidak pernah mengikuti latihan aktivitas fisik dan sebanyak $37,7 \%$ pasien tidak memperhatikan diet. Hasil penelitian juga menunjukkan sebanyak $62,3 \%$ pasien DM Tipe 2 dalam satu minggu terakhir tidak mengikuti olah raga seperti berenang, berjalan, bersepeda dan sebanyak 95,1\% pasien tidak pernah memeriksa kondisi kaki. Hasil temuan penelitian ini sejalan dengan penelitian yang dilakukan oleh Elpriska (2016) tentang manajemen diri terhadap komplikasi ulkus kaki diabetik pada penderita DM Tipe 2 diperoleh hasil sebanyak $82,5 \%$ pasien memiliki manajemen diri rendah

Dalewitz, Khan, dan Hershey, Rubin \& Peyrot (dalam Keers et al., 2004) menyebutkan bahwa banyak pasien DM tipe 2 mengalami kesulitan untuk melakukan 
$\begin{array}{llr}\text { manajemen } & \text { diri } & \text { sehingga } \\ \text { mengakibatkan } & \text { kontrol } & \text { glukosa }\end{array}$ buruk. Hal ini sejalan dengan penelitian Hasanat (2008) yang mendapatkan bahwa sebagian dari pasien mempunyai perasaan tidak nyaman ketika menjalani pengobatan, takut pada saat awal harus diet, mempunyai kesulitan dalam menjalankan diet, merasa jenuh, dan bosan berolahraga.

Hasil penelitian ini juga menunjukkan bahwa lebih dari separoh $(60.7 \%)$ pasien DM Tipe 2 memiliki dukungan sosial yang kurang baik pada penderita diabetes melitus tipe 2 di Poli Klinik Khusus Penyakit Dalam RSUP Dr. M. Djamil Padang. Hal dibuktikan dari hasil pengumpulan data yang memperlihatkan sebanyak $52,5 \%$ pasien tidak memiliki seseorang yang bisa diandalkan untuk mendengarkan pasien ketika perlu bicara, sebanyak $60,7 \%$ tidak memiliki seseorang untuk membawa mereka ke dokter jika pasien membutuhkannya. Hasil penelitian juga menunjukkan sebanyak $65,6 \%$ pasien tidak memiliki seseorang yang selalu memberikan rasa nyaman dan untuk berbagi terhadap kekhawatiran dan ketakutan yang mereka rasakan serta sebanyak $62,3 \%$ pasien juga tidak memiliki seseorang untuk berfikir dengan membantu pasien, maka hal tersebut bisa meringankan beban dari pasien tersebut. Hasil penelitian ini hampir sama dengan penelitian yang dilakukan oleh Rembang (2017) tentang hubungan dukungan sosial dengan perawatan mandiri pada pasien diabetes melitus tipe 2 di poliklinik penyakit dalam RSUD Mokopido Toli-Toli diperoleh hasil sebanyak $75 \%$ pasen memiliki dukungan sosial kurang baik.
Berdasarkan hasil penelitian menunjukkan bahwa pasien yang memiliki manajemen diri kurang baik lebih banyak ditemukan pada dukungan sosial kurang baik yaitu 73\% dibandingkan dengan pasien yang memiliki dukungan sosial baik yaitu $29.2 \%$. Hasil uji statistic (chi square) diperoleh nilai $\mathrm{p}=0.002 \leq$ 0.05 , maka dapat disimpulkan bahwa terdapat hubungan yang bermakna antara dukungan sosial dengan manajemen diri di Poli Klinik Khusus Penyakit Dalam RSUP Dr. M. Djamil Padang tahun 2017. Sejalan dengan penelitian yang dilakukan oleh Elpriska, (2016) tentang pengaruh dukungan keluarga terhadap manajemen diri pada pasien diabetes melitus tipe 2 diperoleh hasil terdapat pengaruh dukungan keluarga terhadap manajemen diri dimana dukungan keluarga yang baik maka akan meningkatkan manajemen diri pasien.

Ada beberapa faktor yang mempengaruhi manajemen diri pada pasien DM diantaranya yaitu dukungan sosial, social environmental support dan social problem-solving. Keberhasilan pengelolaan diabetes melitus tergantung pada informasi tentang diabetes melitus tipe 2, dari keluarga untuk melakukan perawatan diri yang dirancang untuk mengontrol gejala psikologis maupun komplikasi menurut $\mathrm{Wu}$ et al. (2006 dalam Ariani, 2011). Selain itu dukungan sosial yang kuat berpengaruh positif dengan partisipasi dalam perilaku manajemen diri (King et al., 2010 dalam Hunt et al., 2012).

Dukungan sosial merupakan prediktor penting dalam perilaku perawatan diri pada pasien DM. Ketika pasien didiagnosis dengan 
penyakit kronis, maka pasien tersebut memerlukan bantuan perawatan diri dari teman dan keluarga. Menurut ahli bahwa pasien DM tipe 2 yang melakukan perilaku perawatan diri yang lebih baik ketika menerima dukungan dari keluarga dan teman-temannya dan begitu juga sebaliknya (Bai, Chiu \& Chang, 2009). Dukungan sosial sangat membantu penyandang DM tipe 2 untuk meningkatkan kontrol terhadap diabetes, karena tipe atau karakter orang Indonesia yaitu selalu membutuhkan dukungan dari orang lain terutama dalam kondisi sakit. Kurangnya dukungan sosial berdampak pada rendahnya aktivitas pasien DM, distres emosional yang lebih besar, ketidakaturan dalam kebiasaan diet dan menurunnya frekuensi untuk pemeriksaan kaki (Hadjam, dkk, 2014). Emilia (2015) melaporkan bahwa bantuan sosial sangat membantu pasien DM tipe 2 untuk meningkatkan kontrol terhadap diabetes, karena jika dukungan sosial kurang maka akan berdampak pada rendahnya aktivitas pasien DM yang mengalami stres emosional karena perawatan yang lama sehingga menyebabkan ketidakaturan dalam kebiasaan diet dan menunrunnya frekuensi untuk pemeriksaan kaki.

\section{KESIMPULAN}

Berdasarkan penelitian ini dapat disimpulkan bahwa bahwa lebih dari separoh $(55.7 \%)$ pasien DM tipe 2 memiliki manajemen diri yang kurang baik dan lebih dari separoh $(60.7 \%)$ pasien DM tipe 2 memiliki dukungan sosial yang kurang baik. Penelitian ini juga mendapatkan bahwa terdapat hubungan yang antara dukungan sosial dengan manajemen diri pasien DM Tipe 2.

\section{UCAPAN TERIMAKASIH}

Terimakasih peneliti ucapkan kepada semua pihak yang telah mefasilitasi penilitian ini meliputi semua responden yang terlibat, pimpinan RSUP Dr. M.Djamil Padang serta pimpinan STIKes MERCUBAKTIJAYA Padang

\section{DAFTAR PUSTAKA}

Ariani, Y. (2011). Hubungan Antara Motivasi dengan Efikasi Diri Pasien DM Tipe 2 Dalam Konteks Asuhan Keperawatan Di RSUP. $H$. Adam Malik Medan. Tesis. Universitas Indonesia.

Astuti, Neneng. (2014). Efikasi diri dan manajemen pada pasien diabetes tipe 2. Tesis. Fakultas Keperawatan Universitas Sumatera Utara

Bai, Y, L., Chiou, C, P., \& Chang, Y. Y. (2009). Self-care behavior and related factors in older people with type 2 diabetes. Journal of Clinical Nursing, 18, 3308-3315. Diakses dari http://dx.doi.org/10.1111/j.13 65-2707.2009.02992.x

Elpriska (2016). Pengaruh Stres, Dukungan Keluarga dan Manajemen Diri Terhadap Kompliksi Ulkus Kaki Diabetik Pada Penderita DM Tipe 2

Emilia (2015). Dukungan Sosial dan Perlaku Perawatan Diri Penyandang Diabetes Melitus Tipe 2. Diunduh dari: 
https://www.poltekkeskupang .ac.id/informasi/download/cat egory/25jurnal11-

2015.html?download=161:hal -952-966-dukungan-sosialdan-perilaku-perawatan-diripenyandang-diabetes-melitustipe-2-emiliaerningwati-akoit.

Hadjam , dkk (2014). Hubungan Antara Dukungan Sosial Keluarga dengan Perilaku Makan Padan Penderita Diabetes Melitus Tipe 2 di Yogyakarta. Diunduh dari: http://opac.unisayogya.ac.id/7 32/1/NASKAH\%20PUBLIK ASI.pdf

Hasanat, N, U. (2015). Manajemen Diri Diabetes Analisis Kuantitatif Faktor-Faktor Psikososial Pada Pasien Diabetes Melitus Tipe II. Disertasi. Universitas Gajah Mada.

Hasanat, N.U. (2008). Aspek psikologik pada pasien diabetes dan keluarga pasien diabetes melitus dalam manajemen diabetes melitus: Studi eksplorasi. Laporan Penelitian tidak diterbitkan. Fakultas Psikologi UGM, Yogyakarta.

Hunt, C. W., Wilder, B., Steele, M. M., Grant, J. S., Pryor, E. R., \& Moneyham, L. (2012). Relationships among selfefficacy, social support, social problem solving, and self-management in a rural sampel living with type 2 diabetes mellitus. Research and Theory for Nursing Practice: An International Journal, 26(2), 126-141. doi:10.189/1541-

6577.26.2.126.

IDF (International Diabetes Foundation Diabetes) (2013). IDF Diabetes Atlas, http://www.idf.org/atlasmap/a tlasmap

Keers, J. C., Links, T.P., Bouma,J., Gans, R.O.B, ter Maaten, J.C., Wolffenbuttel, B.H.R., Sluiter, W.J., et al. (2004). Do diabetalogists recognise selfmanagement problems in their patients? Diabetes Research and Clinical Practice, 66, 157-161. doi: 10.1016/j.diabres.2004.02.01 8

PERKENI. (2011). Konsensus pengelolaan dan pencegahan diabetes melitus tipe 2 di Indonesia. Jakarta.

Purwanti, O.S 2013. Analisis FaktorFaktor Risiko Terajdinya Ulkus Kaki pada Pasien Diabetes Mellitus di RSUD DR.Moewardi Surakarta, Prosiding Seminar Ilmiah nasional, ISSN: 2338-2694, http:///journal.ui.ac.id/index.p hp/jkepi/article/view/2763

Rembang, VP. (2017). Jurnal Hubungn Dukungan Sosial dan Motivasi dengan Perawatan Mandiri pada Pasien Diabetes Melitus Tipe 2 Di Poliklinik Penyakit Dalam RSUD Mokopido Toli-Toli.

Riset Kesehatan Dasar , (RISKESDAS 2014) . Badan penelitian dan pengembngan kesehatan serta prevalensi diabetes melltus. Jakarta 
WHO, 2013, Diabetes Fact Sheet,

http://www.who.int/mediacen

tre/factsheets/fs312/en/ 